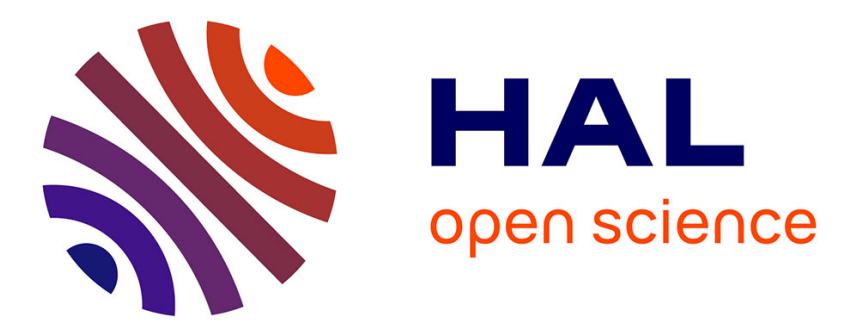

\title{
Kunara, a Bronze Age City on the Upper Tanjaro (Iraq)
}

Aline Tenu, Christine Kepinski

\section{To cite this version:}

Aline Tenu, Christine Kepinski. Kunara, a Bronze Age City on the Upper Tanjaro (Iraq). 9th International Congress on the Archaeology of the Ancient Near East, Jun 2014, Bâle, Switzerland. pp.147 - 159. halshs-02359920

\section{HAL Id: halshs-02359920 \\ https://shs.hal.science/halshs-02359920}

Submitted on 12 Dec 2019

HAL is a multi-disciplinary open access archive for the deposit and dissemination of scientific research documents, whether they are published or not. The documents may come from teaching and research institutions in France or abroad, or from public or private research centers.
L'archive ouverte pluridisciplinaire HAL, est destinée au dépôt et à la diffusion de documents scientifiques de niveau recherche, publiés ou non, émanant des établissements d'enseignement et de recherche français ou étrangers, des laboratoires publics ou privés. 


\section{Aline Tenu - Christine Kepinski}

\section{Kunara, a Bronze Age City on the Upper Tanjaro (Iraq)}

The archaeological expedition to Peramagron undertakes excavations at Kunara since 2012. This 7-10 hectare site, situated on the bank of the Tanjaro river, is one of the largest of the area. The results of the two first seasons show that Kunara was a Bronze Age centre characterized by several monumental buildings.

In 2011, the Mission archéologique française du Peramagron undertook a survey in the Upper part of the Tanjaro Valley and in the neighboring valley of the Taynal River, between the pass of Bazian and the modern city of Arbat (fig. 1). 31 sites were identified (Kepinski 2014, Tenu i. p.), and three retained our attention, Bingird, Kalespi and Kunara because of their size, of their location, and of the possible occupation levels. Among them Kunara, located $5 \mathrm{~km}$ south-west of Suleymaniyah, was the largest, almost 10 ha and showed the longest sequence from the chalcolithic until the $2^{\text {nd }}$ Millennium, that is why we started to excavate it first, in 2012 and 2013. Kunara lies in a meander of one of the main arms of the Tanjaro River. The ancient topography remains all the more elusive since an asphalted road severely damaged the archaeological deposits, but the site clearly comprised a upper town to the west and a lower town to the east (fig. 2).

\section{The Geomagnetic Survey}

In 2012, before choosing the different excavation areas, a geophysical survey was conducted by Christophe Benech. The most interesting results were obtained on the top of the lower town where a monumental building, more than $60 \mathrm{~m}$ long and $30 \mathrm{~m}$ wide appears clearly on the magnetic image (fig. 3). It is organized around two courtyards roughly $400 \mathrm{~m}^{2}$ to the South and $500 \mathrm{~m}^{2}$ to the North. The building is bordered to the east by several parallel lines, which could indicate rows of rooms around the courtyards. 


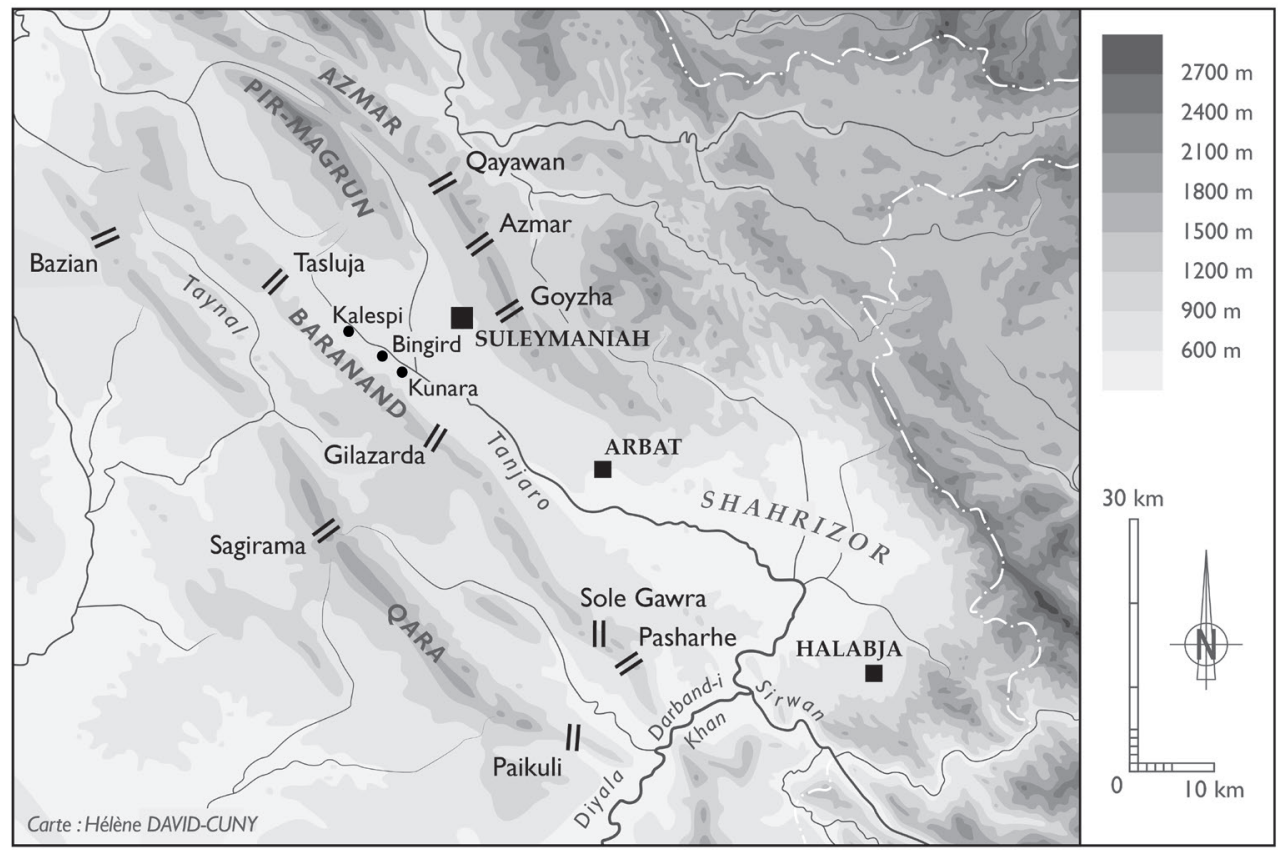

Fig. 1. Map of the surveyed area (H. David-Cuny).

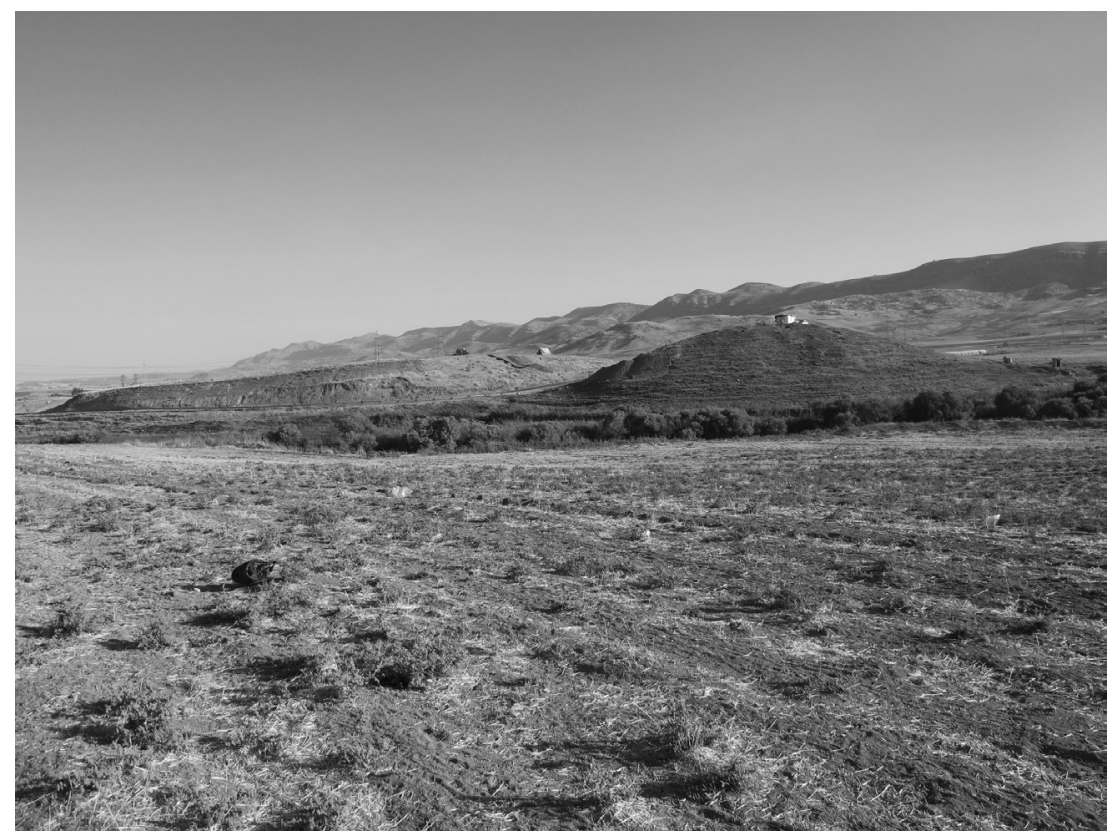

Fig. 2. Kunara seen from the North-West. In the background, the Baranand range (A. Tenu). 


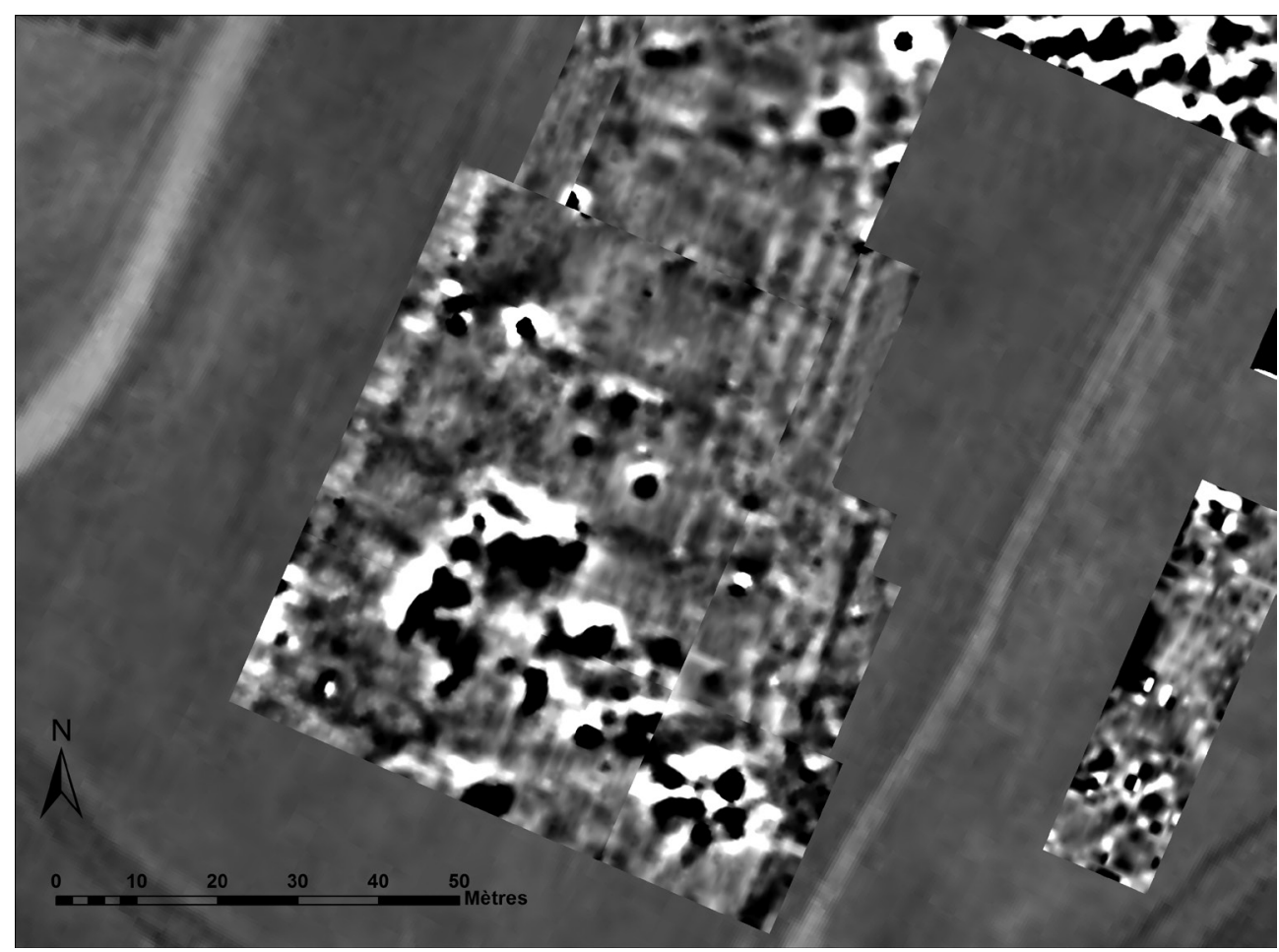

Fig. 3. Geomagnetic map of the Lower Town of Kunara (Chr. Benech).

To the south the black dots may reveal buildings erected with baked bricks, or burnt buildings. Two orientations are visible and probably correspond to two different levels. Unfortunately the steep slopes of the upper town preclude conducting such a survey there (see for more details the presentation written by Christophe Benech in Kepinski et al. i. p.).

\section{The Excavations 2012-2013}

In 2012, three areas were implemented, one on the upper town, area A, a stratigraphic trench and two on the lower town where remains appeared on the magnetic map. In 2013, a new one, D was opened with two step trenches, one to the west and one to the south in order to investigate if Kunara was surrounded by a defensive system (fig. 4). 


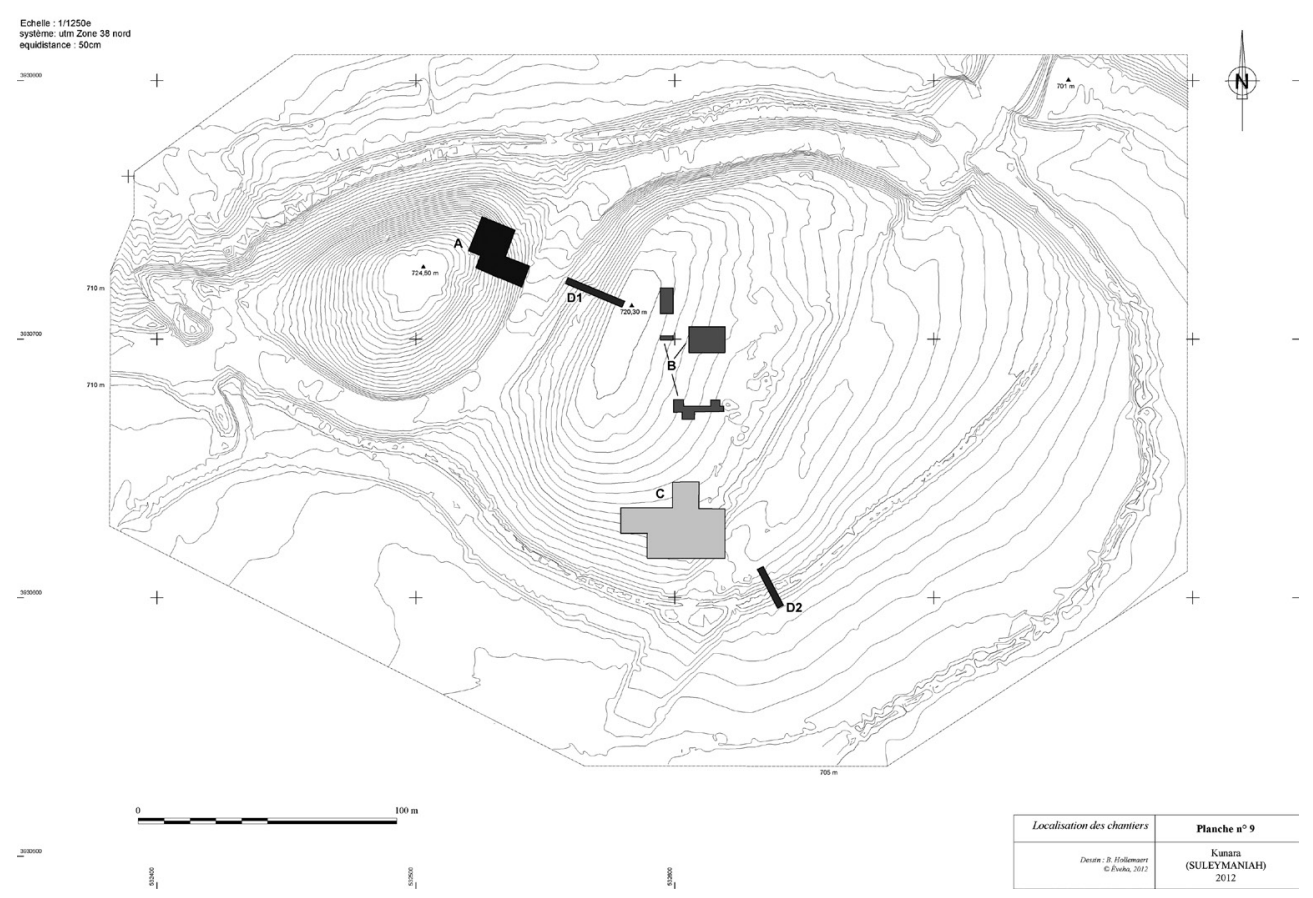

Fig. 4. Topographical map of Kunara (Boris Hollemaert).

\section{Area A (2012-2013 - Christine Kepinski)}

The first goal of the area A was to establish a stratigraphic sequence, which could be used as reference for other areas. A trench 5 meters wide was thus dug. It reveals a monumental building, deliberately filled with earth carefully prepared. The dating, and the reasons of this filling (level 1) remain unclear because the upper part of the tell has not yet been explored.

So far, only the north-eastern part of the monumental building (level 2) has been cleared. The building comprised a large space, probably a courtyard, which measures at least $100 \mathrm{~m}^{2}$. It was delimited to the north and to the east by two walls, $2.60 \mathrm{~m}$ thick, built on massive stone bases (fig. 5). The northern wall is rather well preserved, and shows a very intriguing construction technique: single layers of rectangular mudbricks, protected by diluted bitumen and jointed with a mortar containing crushed bones, alternated with about $0.60 \mathrm{~m}$ of pisé. Two different floors, prepared with pebbles, were identified. The lower floor has been abandoned and yielded some crushed pots whereas the upper one was plastered and incompletely cleaned out before a heavy fire. A terracotta water pipe about $10 \mathrm{~m}$ long allowed water drainage from the courtyard; it runs north, through a room which marked the northern limit of the monumental building. 


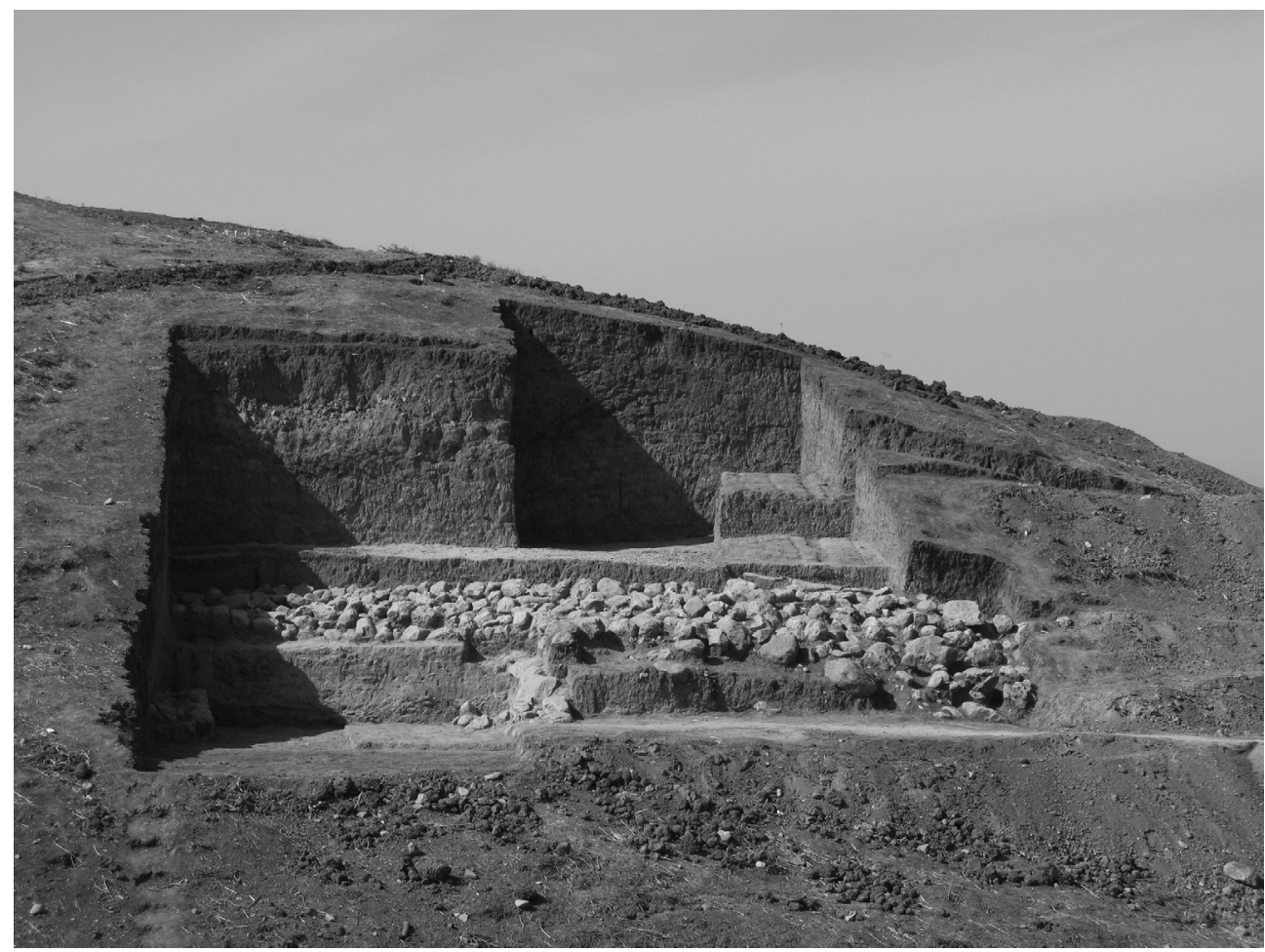

Fig. 5. Area A. The north-eastern angle of the monumental building (level 2) (C. Kepinski).

Walls of this building rested on the remains of an older one (level 3), which seems to have roughly the same plan even if walls, reinforced by buttresses, were clearly thinner: $0.70 \mathrm{~m}$ instead of $2.60 \mathrm{~m}$. Two different phases of occupation are attested: under the lower floor we excavated a drain covered by flat stones. Surprisingly, floors were laid before the walls were built, without foundations.

These two successive buildings were erected on the top of a huge platform made of sand. This artificial terrace is at least $3.5 \mathrm{~m}$ high (we do not reach its base), and it covered, sealed and probably partly destroyed the previous levels. A stairway, $7 \mathrm{~m}$ long and $0.90 \mathrm{~m}$ wide, gave access to the top of the platform. It was built on stone foundations and comprised at least one landing. On the top of the platform, a free space was left along the building. Originally it reached $4.40 \mathrm{~m}$ wide but it was later shortened to $2 \mathrm{~m}$. The platform was surrounded by an enclosure wall, built with an external facing made of large boulders.

We do not yet know what may have been the extent of the monumental building and of the platform on which it was erected but they probably occupied a large part of the upper town. 


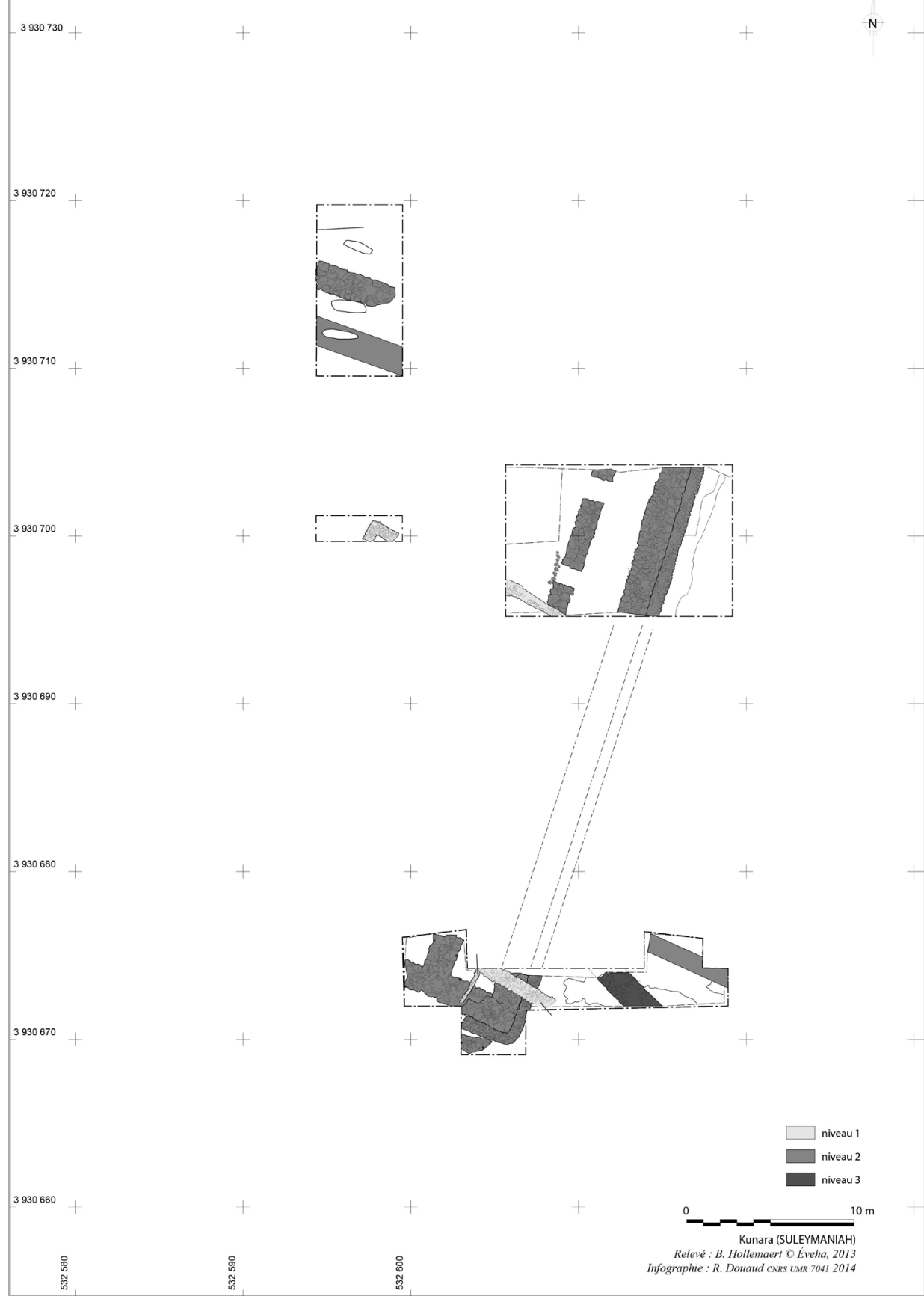

Fig. 6. Area B. Schematic map of the architectural remains (B. Hollemaert, R. Douaud). 


\section{Area B (2012-2013 - Aline Tenu)}

Area B is aimed to excavate the monumental building identified by the geomagnetic survey. For this purpose, we opened four different sectors in which three main occupation levels were recognized (fig. 6).

The most recent level (level 1) is attested in three sectors. The remains consist in stone foundations, only one course high, and maximum $0.60 \mathrm{~m}$ thick. They were very close to the surface and consequently rather badly preserved: the floors as well as the elevation were not found. The dating of this level is thus still uncertain, but one of them was however clearly founded on the decayed pisé of the previous level.

Level 2 corresponds to the monumental building we were looking for. Two of the three parallel walls seen to the east of the geomagnetic map were found: they measure at least $35 \mathrm{~m}$ in length. Two walls of the northern part of the building were also discovered, and we put in light the wall which marked the southern limit of the northern sector seen on the magnetic image. Generally speaking, walls are built with massive stone footings, more than $1.30 \mathrm{~m}$ thick. They usually have two facings made of uncut blocks (sometimes more than $0.80 \mathrm{~m}$ long), and a filling of smaller stones. The easternmost wall was completed by a low bench about $0.80 \mathrm{~m}$ wide and to the east by a layer of pebbles.

The preserved elevation of the walls shows very interesting construction techniques, which surprisingly differ within the building itself. While the superstructure of some presents an alternation of pisé and mudbricks, the elevation of others is made with uneven layers of pisé or of cob. This is the case of the northern walls of the building. Two different techniques seem to have been used for the wall in the northeast trench (still more than $1.80 \mathrm{~m}$ high): homogenous earth was laid on the stone footing and then recovered by rammed earth, whose layers are still visible.

An oldest level (level 3) has been recognized: indeed we discovered a thick wall deliberately levelled and covered by the pebbles layer associated to level 2. Its different orientation suggests it belongs not to an older phase of the building but to an older edifice, which was also probably a monumental construction.

\section{Area C (2012-2013 - Nordine Ouraghi)}

Area $\mathrm{C}$ was intended to study later occupation of the site. To this end, about $600 \mathrm{~m}^{2}$ were opened. They conveyed to a depth of less than $0.50 \mathrm{~m}$ remains of three different levels.

Very near the surface (level 1), three buildings oriented NO-SE and separated by passageways (one measuring more than $5 \mathrm{~m}$ wide) have been partly cleaned. The stone footings between 0.45 and $1 \mathrm{~m}$ in thickness were laid on the ruins of both level 2 and 3. Their floor and elevation are not preserved but numerous fragmentary mudbricks suggest the superstructures were built that way. A grindstone, several pestles and buffer as well as sherds of storage jars indicate the central building was probably devoted either to food preparation, 


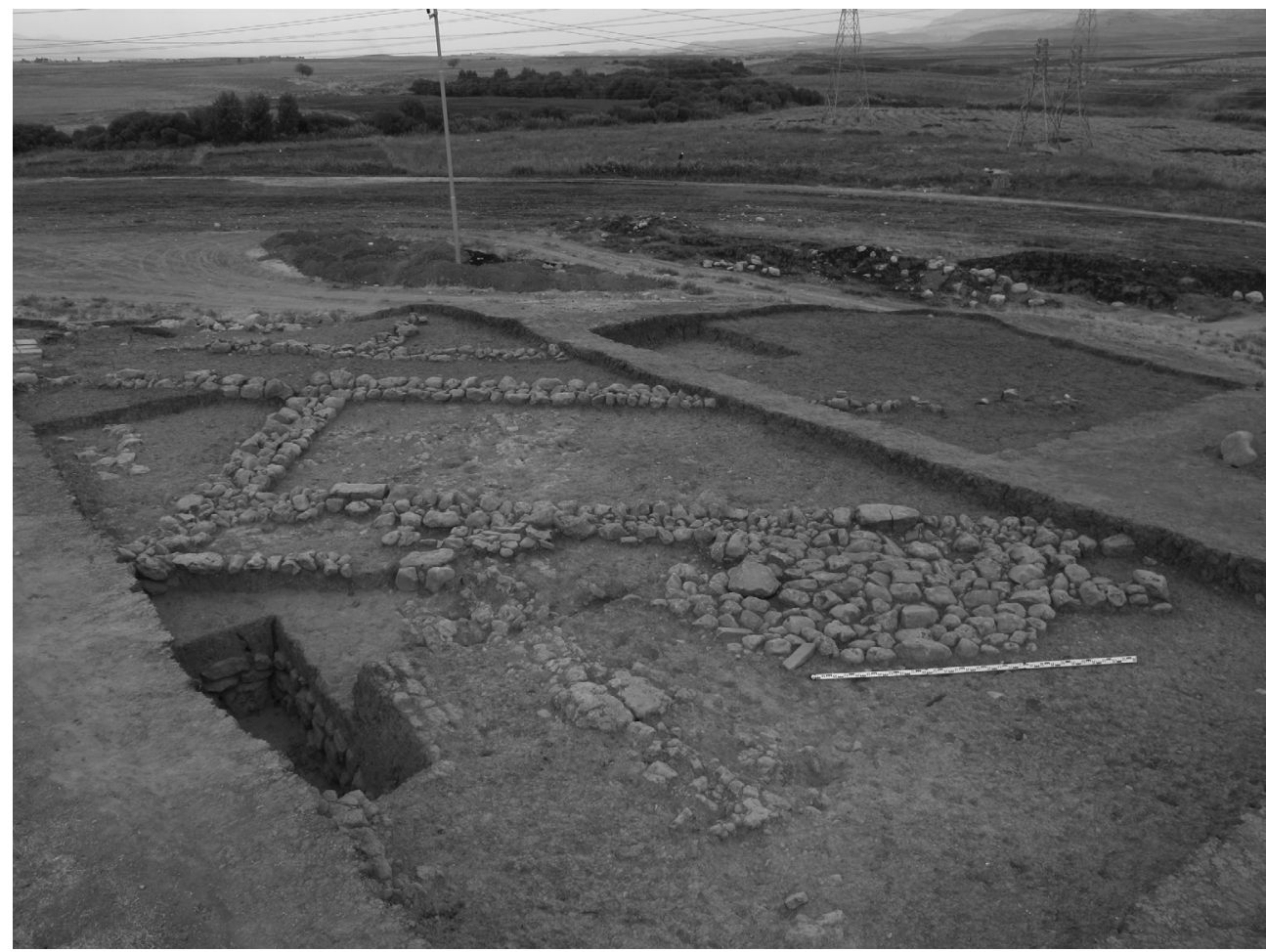

Fig. 7. Area C: Sounding in a room of the burnt building (level 3). Above, stone footings of level 1 (N. Ouraghi).

or to craftsmanship. Unfortunately archaeological deposits belonging to that level, significantly eroded, are poorly preserved.

The floors of level 2 were found directly on the top or against the walls of level 3. Contrary to level 1, the structures of level 2, as well as those of level 3, are oriented North-South and East-West. Level 2 is characterized by a monumental complex, whose limits are unclear because later works has damaged it. It was reached by an outside staircase located to the east.

On the top of it, a paved passage covered with baked bricks marked the entrance to the complex composed by different kind of exterior floors around a public building. Low walls were erected to retain the pebbles layers about $5 \mathrm{~cm}$ thick, which constituted, perhaps the first phase, but more probably the substructure of the floors subsequently covered by backed bricks or by clay plaster. Two terracotta pipes, discovered under the retaining walls, served drainage purpose.

To the north-east, the corner of a monumental building has been found. Its walls, $1.40 \mathrm{~m}$ thick, are carefully built with stone bases. The elevation has almost completely disappeared but was probably made of mudbricks. The doorstep of the entrance, located in the south-east 


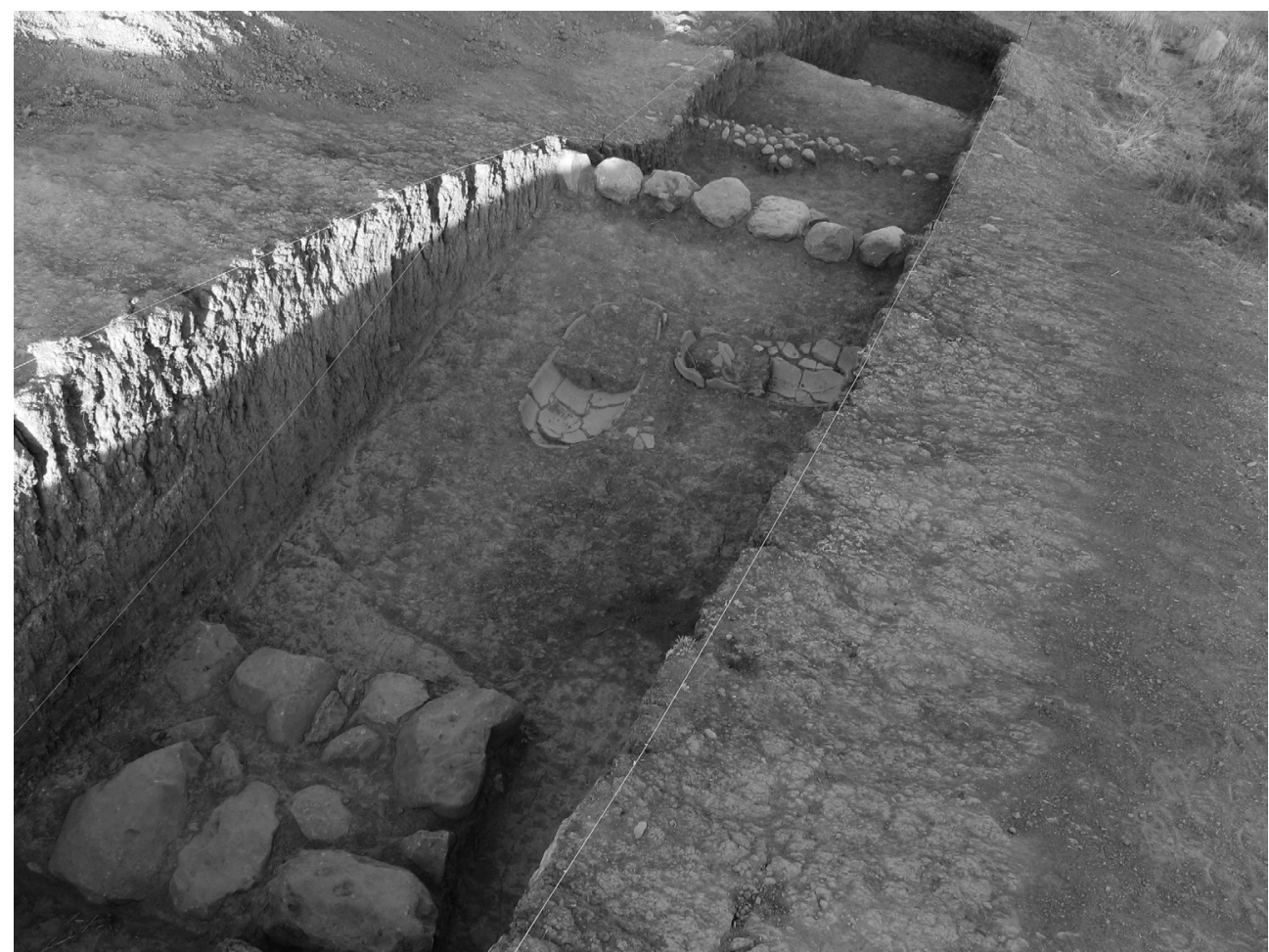

Fig. 8. Area D: Test trench $\mathrm{D}_{1}$ from the east (S. Rey).

corner, was marked with fragmentary baked bricks which were partly covered in a second step by three mud-bricks.

The previous level (level 3) corresponds to a building of which four rooms, heavily burnt, have been identified as yet. A test trench (fig. 7) dug in one of them in 2012 revealed its floor was covered by storages jars. Even if the excavation of this level has been postponed until next season, interesting features have already been observed because of its exceptionally good state of preservation. Indeed parts of the reed roofing have been found on the top of the filling of the rooms, and the mudbricks vault which covered the passage between two of them is preserved almost to its summit. Generally speaking, architectural remains of this area, whatever the level they belong to, indicate a wider use of mudbricks than elsewhere in the site.

The major interest of this area is also its main difficulty: levels are so closely interlocked, that remains of the oldest structures are sometimes higher than those of the recent ones. 


\section{Area D (2013 - Sébastien Rey)}

In 2013, two narrow trenches were put on the slope of the lower town in order to check if Kunara was protected by a defensive system, and to study the stratigraphic relationship between the upper and the lower town.

The first one, $\mathrm{D}_{1}$, is located on the western side of the lower city. Four stratigraphic levels were identified on nearly $8.30 \mathrm{~m}$ of elevation (fig. 8).

The remains of the first level are characterized by a floor -perhaps an open space-, a pisé wall, a retaining wall of blocks of limestone and a badly preserved structure whose original nature is no longer visible. The superstructure of the pisé wall, nearly $1.60 \mathrm{~m}$ thick, is preserved to about $1.50 \mathrm{~m}$; it shows at least 9 layers of rammed earth including limestone nodules. Its footing was made of two regular faces of uncut limestone blocks, and a filling of smaller stones and of pebbles.

The previous level, Level 2, is mainly documented by a tabook floor linked to two big ceramic vessels and a tannour, intentionally levelled. They were buried in the destruction layer that constitutes the level 3. Levels 1 to 3 were separated from the last level by a thick layer of sterile soil.

The level 4 was poorly preserved, but provides nevertheless the northern end of a room. Walls are rather thin, with a maximum thickness of $0.85 \mathrm{~m}$, and are erected with uneven limestone blocks. The upper part is not preserved and there is no evidence whether they were made of mudbrick or of pisé. About $1.80 \mathrm{~m}$ to the south, separated by a lane, another wall (ca. $0.90 \mathrm{~m}$ in width) may have belonged to another building, or perhaps to an enclosure wall. In the small sounding carried out just outside the external wall, the virgin soil was not reached.

In the second trench $\mathrm{D}_{2}(2.50 \mathrm{~m}$ wide and $17 \mathrm{~m}$ long $)$, located on the eastern side of the site, two levels have been recognised. The first one, a floor made of gravel, appeared immediately below the surface. It covered a heterogeneous layer, probably a destruction layer, which covered the remains of a domestic occupation. The latter is characterized by the southern part of a room delimited by three walls about $0.50 \mathrm{~m}$ thick. Its floor made of djuss rested on a layer of gravel. The walls are heavily eroded and only the stone footings are preserved. At least three broken jars were found in situ. The rather homogeneous layer of soil on which this level was erected was excavated to a depth of $1.20 \mathrm{~m}$ without reaching a significant archaeological level. 


\section{Material and Dating}

The architectural structures provided by the four areas are tentatively attributed to three main levels on the basis of the pottery. Whereas the pottery assemblages seem to show a great continuity between level 2 and level 1, ceramics stemming from the earliest level (level 3) is significantly different. Further investigation is needed to confirm, and interpret this rupture in the pottery tradition. Ceramics ascribable to levels 1 and 2 may be related to materiel found in the Diyala area, but displays also good comparisons with corpus from South Mesopotamia.

The most noticeable small finds consist in different kind of beads, an obsidian flint (area $\mathrm{D}_{2}$ ), a bronze pendant (area A), and a lithic arrowhead from a type well attested in the Akkadian period (area $\mathrm{D}_{1}$ ). We also discovered different kinds of pins and needles, and a cylinder seal finely carved in a greenish stone found in the monumental building of area B. It features a religious scene with two worshippers and a goddess. According to Nordine Ouraghi, it dates back to the Akkadian or to the post-Akkadian period (see Kepinski/Tenu i. p.). It finds close parallels in the Diyala region (Frankfort 1955, n. 438) and in Ur and its vicinity.

The material gives a time range from the Early Bronze Age to the Middle Bronze Age, divided provisionally in three main levels, each with several phases:

Level 1, dated to the beginning of Middle Bronze Age (2000-1900), is mainly documented in Area C.

To Level 2, end of Early Bronze (2200-2000), belong the monumental buildings excavated in Areas A and B.

Level 3, which corresponds to the Early Bronze Age between 2350 and 2200, is attested both by Area $A$ and by the lowest level in area $\mathrm{D}_{1}$, but architectural remains ascribable to this level are so far limited.

The dating of levels 1 and 2 is also founded on radiocarbon dates. However this general framework needs to be confirmed, and precised by future investigation. If we convert this periodization in historical terms, we might consider level 1 corresponds to Isin-Larsa, level 2 to Ur III and level 3 to Akkad, but the relevance of this historical terminology in our region certainly deserves further discussion. 


\section{Conclusions}

Kunara appears thus as a small town with a surprisingly high number of large constructions, which show a great diversity in building techniques. Generally speaking walls rested on stone footings. Their elevation were made either of mudbricks, or built with an alternation of earth and mudbricks or just in earth. In the latter case, techniques may also vary, and future research will be devoted to identify more precisely the construction methods (rammed earth, cob a.s.o). One may also notice the ancient inhabitants of Kunara paid a great attention to the systems of water evacuation: pebbles floors and floor preparation, terra-cotta pipes, stone drain.

After just two seasons of excavations it is too early to give a clear picture of the urban layout of the settlement. In particular, the relationship between the different monumental buildings must be cleared up. Some parts of the site might have been surrounded by enclosure walls, but until now no defensive system has been found.

In the $3^{\text {rd }}$ millennium BC, the area around the modern city of Souleymaniyah was probably part of the Lullubum. This land, because of its natural resources and of its strategic location on trade roads toward Iran and beyond, arouse keen interest of Mesopotamian rulers as early as the Akkadian period. The stele, now in the Louvre, Naram-Sin erected was to commemorate his victorious campaign in this region. Šulgi also claimed he subjugated the Lullubum, but the repeated campaigns carried out there reveal the conquest has not been that complete. Written sources show the resistance faced by the Mesopotamian kings who entered the Lullubum, but give almost no indication concerning the land itself, its inhabitants or its organization. We hope the work that has begun in Kunara will contribute to their better knowledge. 


\section{Bibliography}

Kepinski, C., 2014. Research in the Suleymaniyah Province (Iraq): The upper Tanjaro Survey. P. Bieliński et al. (eds.), Proceedings of the 8th International Congress on the Archaeology of the Ancient Near East 30 April - 4 May 2012, University of Warsaw, Volume 2, Wiesbaden, 149-164.

- i. p. Rapport préliminaire sur la première campagne de fouilles à Kunara (Mission Archéologique du Peramagron 2012): niveaux fin Bronze Ancien, début Bronze Moyen. Études Mésopotamiennes - Mesopotamian Studies 1.

Kepinski, C./Tenu, A., 2014. Kunara, ville majeure de la haute vallée du Tanjaro (Irak, Kurdistan, province de Souleymanieh), Routes de l'Orient. Revue d'archéologie de l'Orient ancien, hors série 1, 4-19.

- $\quad$ i. p. Two seasons of excavations at Kunara (Upper Tanjaro): an Early and Middle Bronze Age city. K. Kopanias/J. MacGinnis (ed.), Archaeological Research in the Kurdistan of Iraq and the adjacent areas, Oxford.

Kepinski, C./Tenu, A. et al., 2015. Kunara, petite ville des piedmonts du Zagros à l'âge du Bronze: rapport préliminaire sur la première campagne de fouilles, 2012 (Kurdistan Irakien). Akkadica 136, 51-88.

Tenu A., i. p. Prospection dans la haute vallée du Tanjaro. Mission archéologique française du Peramagron 2011. Études Mésopotamiennes - Mesopotamian Studies 1.

Aline Tenu, CNRS - UMR 7041 ArScAn, Nanterre.

Christine Kepinski, CNRS - UMR 7041 ArScAn, Nanterre. 